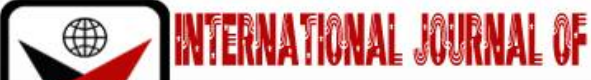

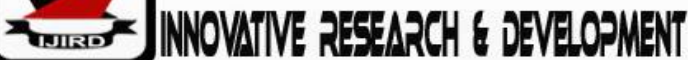

ISSN 2278 - 0211 (Online)

\section{An Assessment of the E-learning Technology to the Teaching and Learining of Music Education}

\author{
Thompson, Elijah Olagoke
}

Chief Lecturer, Department of Cultural and Creative Arts

Michael Otedola College of Primary Education, Noforija-Epe, Lagos State, Nigeria

\begin{abstract}
:
The study was carried out to investigate the E-learning Technology to the Teaching and Learning of Music Education in five Colleges of Education in Lagos State Nigeria. Nigeria arising from the observation that E-learning Technologies to the Teaching and Learning of Music Education has a great challenges facing human race. This study adopted the Descriptive Survey Research of Ex-Post facto type. The population of this study comprised all three hundred level. Students of Music Education and their Teachers in South West Nigeria Colleges of Education as at 2017/2018 academic section. The findings showed that significant population of the respondents of the study had a low knowledge of what E-learning in music as well as its causes and effects on human existence.
\end{abstract}

Keywords: E-learning, technologies, music education, teaching \& learning

\section{Introduction}

The development of any nation to a large extent depends mainly on its advancement in science and technology. In other words internet technology is indispensable in achieving goals of national development. It is in the light of this that promotes effective teaching and learning in Music education student and it cannot be over emphasized.

In the present day, internet technology has become bedrock of all academic activities at all levels of study. Hence, internet is the most popular resources which has been embraced by the academic community in Nigeria. In advanced countries, internet technology has rapidly changed the face of the educational sector, due to the fact that internet technology involves the operation of programs to communicate directly with the outside world because it consists of millions of computers of all shape and size and it is obvious that internet is playing a fundamental role in the present day basically in the educational sector.

Barke (2003) described internet technology as the integration of computer technology mainly in the form of information management system, which gives users the opportunities to handle text and images, numbers, graph, instructions, sound and music to process information by organizing and re-organizing, storing and retrieving, sorting and analyzing presenting and to communicate.

In this age of globalization, it is important for internet to be integrates into the curriculum of music education at various levels of education, basically in the era of global competition. Oyebola (2007) opined that internet technology provides valuable and rich source of information not only to student but to various professions in different sectors of life.

Furthermore, music under the preparation and mobilization of learners for the purpose of enabling them to cultivate awareness and understanding that would reform into citizen, skills competent, moral, values and contribute positively to the economic, social, development of their society. The wide content of internet technology has a great potential for promoting awareness and understanding in learners. The internet which serves as a link to various computers all-round the globe will be of advantages at solving educational problems identified in music at the basic level such as update of curriculum, balancing of standard in teaching and learning of music education and a lot more. As a matter of fact, the internet is a school on its own which covers a large range of information in all diversity of education. In both developing and developed countries, music have discovered that internet technology oriented education is very important to this end, the idea of introducing internet technology into music education has become a survival need of the society and not optional. It has been discovered that to achieve internet technology stability in promoting effective teaching and learning in music education at all levels, computer education is very important because it serves as the channel through which internet technology oriented studies for all ages of students is conveyed. The pursuit of academic excellence has been one of the major concerns for many stakeholders in the educational sectors. But as a matter of fact, to achieve it at the long run, the internet has been the great source for such an academic excellence for the attributes the internet possesses, it has the efficiency of promoting the standard of music education most musically at upper basic level. It is believed that the involvement of an internet facility will accommodate a high cost and as matter of fact, the music must inject such huge amount of money so as to have standard internet facilities for educational purpose not for music education. Also the 
primary level which seems to be the stepping stone to the upper basic must also be aware of the use of internet. Teachers also should be aware of the use and functionality of the internet.

Today in the 21st century technology (IT) has contributed tremendously to the teaching and learning process in different disciplines including music education which has improve the standard of teaching and learning at all levels. Internet is an international computer network connecting other computer networks to communicate directly and also enable it to provide adequate information for w+ individual equally. Moreover, before the advance of internet technology, teaching and learning does not enable enquiry method which would enable the student to explore unlimited resources available on the internet, the only method of enquiry was the textbooks but sometimes, these textbooks are scarce to found. However, the internet has become the most popular information technology resources which have been embraced by Nigeria community, it has been used to solve the problem of scarcity of textbooks and enables students in Nigeria to interact with colleagues from different part of the world to gain more knowledge with internet technology. Teaching and learning has been made simple through E-learning which enable an individual to learn from distance away from the classroom. Thus, student also use internet to interact and to find useful information for academic purposes and also for their social activities with the proliferation of cyber café, which will enable them to learn at their own pace and time as the internet can be assessed anytime of the day and it would makes instructions to be less teachers centered as students learn curiously by searching the internet. Moreover, textbooks are often outdated but most website resources are often current and updated frequently. Hence, it would be important that student in Nigeria should take advantage of these and prepare more for global competition in society. Therefore, teacher must provide opportunity for students to use technology during the process of teaching and learning in order to assess information, apply information in problem solving and their solution. These would make the student to be critical consumer of information in order to create a coherent product. Thus, it has a lot to learn and to gain. The purpose of the internet is for us to explore and make use of the various aspect of it.

Ehaman and Glenn (2002) and Tancook (2003) also support the fact that integration of internet technology in the music education curriculum will enhance teaching in this subject to the fact that, of other disciplines an eclectic distillation including, history, music, geography, anthropology, psychology, economics, religious studies, agriculture, science, medicine, technology etc. need the internet to explore information. The use of internet technology which has a rich and wide content will provide access to an inexhaustible source of reading materials which will greatly enhance the teaching and learning of political science in Nigeria. Thus, political science educators must accept responsibility for involving learning variety of classroom activities; these activities should provide opportunity for the learners to practice appropriate behavior. Furthermore, internet technology which is multimedia and student centered in nature, as a teaching technique in music will go long way to enhance teaching and learning in this area.

- It enables the student to know more about the global environment; the internet contains a rich source of information that the music student will find useful.

- Tancook (2002) opines that the internet allow the student to see places they had never heard. The image from site provides information that student could not have gained.

- It exposes students to research questions, web question are based on inquiry method which is a teaching and other techniques. It also involves conducting question and search into problems. When using inquiry method the teacher involves the student to collect, assimilate and investigate information. The information is used by the researcher to answer question which is needed on the internet to solve problem.

- To the fact that student are allowed to use their own computer at their own pace (time) is more of an enquiring method of finding solution to a particular problem.

- The enquiring method allows student to play active roles in class activities unlike the traditional lecture method which is more teacher centered.

Coulter, et al (2000) includes some of the benefits of using internet technology for education which are as follows:

- Allows the users to engage in enquiring by exploring merely unlimited resources available on the internet.

- Textbooks are often outdated but most website resources are often current and updated frequently.

- It allows student to learn at their own pace and time as internet can be assessed anytime any day.

- It Provide debt of content for learning in most subject areas.

\section{Literature Review}

The theory upon which this study is built upon is constructivist theory" a theory propounded by jean piaget, a Switzerland philosopher and Natural Scientist in (1972). Some of the relevance's of this study are listed thus:

- The constructivist theory assists our society to the extent that students have the opportunity to be exposed to other idea, culture and forums on global issues.

- The constructivist theory asserts that technology incisively shapes how individuals think, feel, act and how societies organize themselves and operate.

- Constructivism theory also, modifies the role of the teacher so that teachers help students to construct knowledge rather than reproduce a series of facts.

- Also, with the aids of constructivist theory, students can work on collaborative project which may come in the form of networked writing project or the building of separate phases of an engineering project that enables them to received and give instant responses.

- The constructivist theory provides teachers with tools such as problem-solving and inquiry-based learning activities like in e-learning set-up so that students can formulate and test their dears, draw conclusions and inferences, and convey their knowledge in a collaborative learning environment. 
- Constructivist theory encourages students to assess how the activity is helping them to gain understanding by questioning themselves and their strategies, students become expert learners as they learn how to learn, with the use of computers online and /or offline.

\section{Theoretical Review}

\subsection{Conceptualizing of E-learning technologies}

Internet technology is an information highway which is based on the extrapolation of telecommunication. Internet technology is the global connection of many computer and computer network to link together just as telephone enables us to talk to people on the other side of the world. Hence, internet technology offers very use in several field of human endeavor it is a rapid growing of collections with topic from science, technology, education etc. Adegoke (1999) opined that internet technology enable computer network to link two or more computer system placed at different location. Thus, internet technology is a wide content that has a great potential for promoting awareness and understanding to learners. According to the US department of commerce, national telecommunication and information administration (2003) defined internet technology as the computer base on global information system. The internet technology is composed of many interconnected network, which each network may link tens, hundred and even thousands of computers enable them to share information. Internet technology has made possible for people all over the world to communicate with one another effectively and inexpensively, unlike the traditional media such as radio and television. However, internet technology has brought new opportunity to government business and education. Today, government uses the internal communication.

\subsection{Concept of Music Education}

Music is used to convey detailed behaviors' that are expected of young adults and discourages unacceptable behaviors' such as engaging in armed robbery, cultism, etc. Songs of ridicule are also employed by peer a group to which individual belongs in the community. Therefore, every member of the community is fully aware of what will befall anyone who has been caught in acts regarded as against the norms of the society. The texts of such songs may often have an educational or moral lesson, and there are some societies where children sing about, and ridicule, their mates for committing silly offences such as stealing, bed wetting, lying, etc.

Music is a common denominator that connects people all over the world often able to transcend culture and language barriers; music is a thread woven throughout our shared humanity. The power of music is recognized globally in its ability to teach young people about life-saving messages of hope to the people especially the young ones. Music is thus one of the media used in communicating messages of HIV/AIDS awareness and prevention. Music also allows others to connect with people regardless education, language and background. For example, in a project called 'ZhiriMuzikoy" meaning (live with music) was created. Its forms were to reach out vulnerable youths through a unique music context.

Today in the $21^{\text {st }}$ century technology (IT) has contributed tremendously to the teaching and learning process in different discipline including music which has improve the standard of teaching and learning at all level. Internet is an international computer network connecting other computer network to communicate directly and also enable it to provide adequate information to individual equally.

Moreover, before the advance of internet technology, teaching and learning does not enable enquiry method which would enable the student to explore unlimited resources available on the internet, the only method of enquiry was the textbooks but sometimes, these text books are scarce to fund. However, the internet have become the most popular information technology resources which has been embraced by Nigeria community, it has been used to solve the problem of scarcity of textbooks and enable students in Nigeria to interact with colleagues from different part of the world to gain more knowledge with internet technology. Teaching and learning has been made simple through E-learning which enable an individual to learn from distance away from the classroom. Thus, student also use internet to interact and to find useful information to the academic and also to their social activities with the proliferation of cyber café, which will enable the student to learn at their own pace and time as the internet can be assessed anytime of the day and it would make instructions to less teachers centered as student curiosity derived their learning.

Moreover, textbooks are often outdated but most website resources are often current and updated frequently. Hence, it would be important that student in Nigeria should take advantages of these and prepare more for global competition society. Therefore, teacher must provide opportunity for the student to use technology during the process of teaching and learning in order to assess information, apply information in problem solving and sharing their solution.

These would make the student to be critical consumer of information in order to create a coherent product. Thus, it has a lot to learn and to gain. The purpose of the internet is for us to explore and make use of the various aspect of it.

Ehaman and Glenn (2002) and Tancook (2003) also support the integration of internet technology, the curriculum will enhance teaching in music subject to the fact that, music is an eclectic distillation of many

Subjects including, history, government, geography, anthropology, psychology, economics, religious studies, agriculture, science, medicine, technology etc need the internet to explore information. The use of internet technology which has a rich and wide content will provide access to an inexhaustible source of reading materials which will greatly enhance the teaching and learning of music in Nigeria. Thus, music educators must accept responsibility for involving learning variety of classroom activities; these activities should provide opportunity for the learners to practice appropriate behavior. Furthermore, internet technology which is multimedia and student centered in nature, as a teaching technique in government will go long way to enhance teaching and learning in this area.

Internet technology is an information highway which is based on the extrapolation of telecommunication. Internet technology is the global connection of many computer and computer network to link together just as telephone enables us 
to talk to people on the other side of the world. Hence, internet technology offers very use in several field of human endeavor it is a rapid growing of collections with topic from science, technology, education etc.

Adegoke (1999) opined that internet technology enable computer network to link two or more computer system placed at different location. Thus, internet technology is a wide content that has a great potential for promoting awareness and understanding to learners. According to the US department of commerce, national telecommunication and information administration (2003) defined internet technology as the computer base on global information system. The internet technology is composed of many interconnected network, which each network may link tens, hundred and even thousand of computers enable them to share information. Internet technology has made possible for people all over the world to communicate with one another effectively and inexpensively, unlike the traditional media such as radio and television. However, internet technology has brought new opportunity to government business and education. Today, government uses the internal communication.

In the teaching and learning process of music education is to discover the principle that should be adhered to in public affairs and to study the operation government in order to demonstrate what is good, to criticize what is bad or inefficient and to suggest way of improvements. Music is used to convey detailed behaviors that are expected of young adults and discourages unacceptable behavior's such as engaging in armed robbery, cultism, etc.

Songs of ridicule are also employed by peer group to which individual belongs in the community. Therefore, every member of the community is fully aware of what will befall anyone who has been caught in acts regarded as against the norms of the society. The texts of such songs may often have an educational or moral lesson, and there are some societies where children sing about, and ridicule their mates for committing silly offences such as stealing, bed wetting, lying, etc.

Music is a common denominator that connects people all over the world often able to transcend culture and language barriers, music is a thread woven throughout our shared humanity. The power of music is recognized globally in its ability to teach young people about life-saving messages of hope to the people especially the young ones. Music is thus one of the medias used in communicating messages of HIV/AIDS awareness and prevention. Music also allows others to connect with the people regardless education, language, and background. For example, in a project called 'ZhiriMuzikoy' meaning (life with music) was created. Its forms were to reach out vulnerable youths through a unique music contests much like American idols.

The following are some of the benefits student can derive from using internet technology for teaching and learning in music education.

- It enables the student to know more about the global environment; the internet contains a rich sourceof information that the music student will find useful.

- Tancook (2002) opines that the internet allow the student to see places they had never heard. The image from site provides information that student could not have gained.

- It exposes the student of research question, web question are based on inquiry method which is a teaching and any techniques, and it involves conducting question and search into problems. When using inquiry method the teacher involves the student to collect, assimilate and investigate information.

- The information is used by the researcher to answer question which is needed on the internet to solve problem.

- To the fact that student are allowed to use their own computer at their own pace (time) is more of an enquiring method of finding solution to a particular problem.

- The enquiring method allow student to play active roles in class activities unlike the traditional lecture method which is more teacher centered.

Coulter, et al (2000) include some of the benefit of using internet technology for education which is as follows:

- Allows the users to engage in enquiring by exploring merely unlimited resources available on the internet.

- Textbooks are often outdated but most website resources are often current and updated frequently.

- Instruction is fewer teachers centered as student curiosity derive their learning.

- Allow student to learn at their own pace and time as internet can be assessed anytime any day.

- Provide debt of content for learning in most subject areas.

\subsection{The Effect of Internet Technology in Promoting Teaching and Learning in Music}

The following are some of the effect of internet technology in promoting effective teaching in music education.

\subsubsection{Extend Learning beyond What Could Be Done without Internet Technology}

Internet technology opens the door to learning music skill and content in ways impossible in the traditional classroom. The government teachers in today's classroom can use internet technology to extent learning opportunity for student.

Teacher education can be most effective taking full advantage of internet technology by introducing student to activities in which skills and content are taught more effectively and meaningfully. We caution, however, against using internet technology for technologies sake and encourage pre-service teacher to consider if the internet technology allows them to learn in a way they could not without the internet technology or if they are at least learning in a more meaningful way. One example of how we can use internet technology to prepare government teacher to extend learning in a meaningful way is by using digital achieves such as the one found at the Virginia Centre for digital history.

The Virginia Centre for digital history mission in developing high quality, well researched and reliable history materials for the World Wide Web and deliver them to schools, college, library, historical society, and the general public. Using the digital achieves to primary source available on line through the Virginia center for digital history, student can 
conduct historical research to construct the significant of people and event of history. The materials provide student with opportunity to assess, manipulate and interpret raw materials of our past.

\subsection{Factors Militating against Internet Technology towards Effective Teaching and Learning of Music Education}

Internet technology has contributed effectively towards the teaching and learning of government in other countries, but in Nigeria, there are some factors that are militating against effective teaching and learning of music which are as follows:

\subsubsection{Inadequate Electricity Supply}

This is one of the factors that is affecting the effectiveness of internet technology in promoting effective teaching and learning of music education. Thus, this is as a result of irregular power supply or epileptic in power supply which has a lot to do with connection of computer into socket which contains power (electric power) that will enable it to function in a classroom settings, due to the fact that power failure is inevitable in Nigeria for now, it has affected the effectiveness of internet technology in teaching and learning of government because without connection the internet cannot work and the management will not want to spend money on fuelling the generator, even they will provide money for fuelling the generator, the consciousness of the amount which will bring about limited time will be there.

Another aspect is the rural area, some of the rural area till date still has not gotten electric power supply and these has made it impossible for them to even think of bringing internet technology in teaching and learning of government in such schools. An example is Okegun Local government of Oyo state.

\subsubsection{High Cost of Internet Equipment and Maintenance}

It has been observed that Nigeria has experienced problems of providing facilities and infrastructure because of the high rate of getting these materials to the grass root learning and sometimes the problem is that most of this operator lack the ability of maintenance culture. Thus, high cost of internet equipment is very expensive of which only few schools can afford.

Majority of the school/student have interest in internet but because of the high cost and inadequate funds to maintain it has made them to look as if they don't interest in the internet.

\subsubsection{Poor Funding by Government}

This is a situation in Nigeria where by government officers or agency have low contribution towards the implementation of internet technology in schools in order ,to make teaching and learning more effective.

Hence, it has been said that internet technology will facilitate and motivate learning which can be used as instructional materials in any schools subject. Therefore, low interest of government will vigorously affect the effectiveness of internet technology in teaching and learning activities.

\subsubsection{Instability Government Policy}

In Nigeria, the problem of policy making has affected various sectors in the county including education, this policy are basic problem that is affecting the effectiveness of internet technology in teaching and learning process in primary, secondary and tertiary institutions, it is also in Nigeria that government officers utilize public funds for personal event and the regular change of elected leaders also contribute in the past policy implemented.

\subsubsection{Lack of Teachers Knowledge on ICT Training}

Many teachers in Nigeria have not receive basic information communication technology (ICT) training and cannot make use of the internet themselves and such cannot pass this knowledge to their student.

\subsection{Basic Recommendation towards the Factors Militating against Internet Technology in Teaching and Learning Of Music} Education

A few remedies can be suggested. They include the following

Government at all levels and proprietors of schools should ensure that the basic infrastructural facilities required for integrating internet technology in government curriculum such as computer internet access are made available in all primary and secondary schools throughout the federation.

However, in the interim before the facilities are put in place, schools that do not have computers and internet access should make use of cyber café around them.

Because of the importance of ICT to National development, government at all levels and proprietors of school should provide ICT training for all practicing teachers. Teachers should also be taught how they can use internet technology for enhancing teaching and learning of music.

For the implementation of nation policy on education school is to immediately commence the processof integrating ICT into all level of education in Nigeria. This research hold the view that these will go a long way enhancing teaching and learning in these subject.

The national government curriculum when reviewed should include the use of internet among the prescribed teacher student activities internet resource should also be identified as a source of promoting effective teaching and learning of music. 


\section{Results and Discussion}

The attempt is made to analyses the data collected through the use of research instrument in respect of the population on the area of the study.

All analyses carried out in this chapter have been based on the number of respondents to the items on the questionnaire which were administered randomly to selected schools in Epe Local Government Area of Lagos State.

\begin{tabular}{|c|c|c|}
\hline SEX & NUMBER & PERCENTAGE (\%) \\
\hline MALE & 36 & $36 \%$ \\
\hline FEMALE & 64 & $64 \%$ \\
\hline TOTAL & 100 & $100 \%$ \\
\hline
\end{tabular}

Table 1: Distribution of the Respondents by Sex

Table .1 shows that $36 \%$ of the respondents were male while $64 \%$ of the respondents were female.

\subsection{Analysis of the Findings}

Consequently, the researcher has put the findings in a tabular form and simple percentage was used in the analysis of the data collected.

\begin{tabular}{|c|c|c|}
\hline AGE & NUMBER & PERCENTAGE (\%) \\
\hline $10-20$ & 73 & $73 \%$ \\
\hline $21-30$ & 7 & $7 \%$ \\
\hline 31 AND ABOVE & 20 & $20 \%$ \\
\hline TOTAL & 100 & $100 \%$ \\
\hline
\end{tabular}

Table 2: Distribution of the Respondents by Age

Table .2 shows that $73 \%$ of respondents were between $10-20,7 \%$ of the respondents were between $21-30$ and $20 \%$ of the respondents were between 30 and above.

\begin{tabular}{|c|c|c|}
\hline Occupation & Number & Percentage (\%) \\
\hline STUDENT & 74 & $74 \%$ \\
\hline TEACHER & 26 & $26 \%$ \\
\hline TOTAL & 100 & $100 \%$ \\
\hline
\end{tabular}

Table 3: Distributions of the Respondents by Occupation

Table .3 shows that $74 \%$ of the respondents are students while $26 \%$ of the respondents are teachers.

\begin{tabular}{|c|c|c|}
\hline Marital Status & Number & Percentage (\%) \\
\hline SINGLE & 77 & $77 \%$ \\
\hline MARRIED & 23 & $23 \%$ \\
\hline TOTAL & 100 & $100 \%$ \\
\hline
\end{tabular}

Table 4: Distribution of the Respondents by Marrital Status

Table 4 . Shows that $77 \%$ of the respondents were single while $23 \%$ of the respondents were married.

\begin{tabular}{|c|c|c|c|c|c|}
\hline S/N & Strongly Agree & Agree & Strongly Disagree & Disagree & Total \\
\hline 1. & 40 & 43 & 10 & 07 & 100 \\
\hline 2. & 42 & 37 & 11 & 10 & 100 \\
\hline 3. & 20 & 17 & 33 & 30 & 100 \\
\hline 4. & 50 & 36 & 10 & 04 & 100 \\
\hline 5. & 44 & 41 & 10 & 05 & 100 \\
\hline 6. & 43 & 41 & 10 & 06 & 100 \\
\hline 7. & 13 & 21 & 36 & 30 & 100 \\
\hline 8. & 45 & 33 & 12 & 10 & 100 \\
\hline 9. & 30 & 58 & 07 & 05 & 100 \\
\hline 10. & 53 & 36 & 06 & 05 & 100 \\
\hline 11. & 04 & 13 & 36 & 47 & 100 \\
\hline 12. & 12 & 10 & 48 & 30 & 100 \\
\hline 13. & 35 & 12 & 33 & 20 & 100 \\
\hline 14. & 39 & 37 & 14 & 10 & 100 \\
\hline 15. & 13 & 10 & 37 & 40 & 100 \\
\hline 16. & 23 & 22 & 35 & 20 & 100 \\
\hline 17. & 20 & 19 & 31 & 30 & 100 \\
\hline 18. & 20 & 15 & 35 & 30 & 100 \\
\hline 19. & 23 & 18 & 39 & 20 & 100 \\
\hline 20. & 10 & 25 & 35 & 30 & 100 \\
\hline
\end{tabular}


Table 5

\begin{tabular}{|c|c|c|c|}
\hline S/N & Schools & Number & Percentage (\%) \\
\hline 1. & Pobuna Junior Secondary School. & 21 & $21 \%$ \\
\hline 2. & Epe Junior Grammar School. & 24 & $24 \%$ \\
\hline 3. & Alaro Community Junior High School & 15 & $15 \%$ \\
\hline 4. & EpeGrls Senior High School. & 19 & $19 \%$ \\
\hline 5. & OdoObara Junior High School. & 21 & $21 \%$ \\
\hline Total & & 100 & $100 \%$ \\
\hline
\end{tabular}

Table 6: Distribution of the Respondents by Schools

\begin{tabular}{|c|c|c|c|c|c|c|}
\hline Statement & Strongly Agree & Agree & $\mathbf{\%}$ & Strongly Disagree & Disagree & \% \\
\hline 1. & 40 & 43 & $83 \%$ & 10 & 17 & $17 \%$ \\
\hline 2. & 42 & 37 & $84 \%$ & 11 & 10 & $20 \%$ \\
\hline TOTAL & & & $83.5 \%$ & & & $19 \%$ \\
\hline
\end{tabular}

Table 7: Summary of Respondents to Students 1 - 2

Table4.1 shows that 100 respondents respond to statement $1-2$. Therefore, $83 \%$ and $84 \%$ of respondents agreed to the statements $1-2$, while $17 \%$ and $21 \%$ of the respondents disagreed with the statement $1-2$. In all, $83.5 \%$ of the respondents agreed with the research question while $19 \%$ of the respondents disagreed with the research question. Looking at the table, $83 \%$ and $84 \%$ of the respondents agreed to the fact that Music teachers are highly exposed to internet technology and have positive attitude when it comes to the use of computer are internet technology in the teaching and learning of Music education.

\begin{tabular}{|c|c|c|c|c|c|c|}
\hline Statement & $\begin{array}{c}\text { Strongly } \\
\text { Agreed }\end{array}$ & Agreed & \% & $\begin{array}{c}\text { Strongly } \\
\text { Disagreed }\end{array}$ & Disagreed & \% \\
\hline 12 & 12 & 10 & $22 \%$ & 48 & 30 & 78 \\
\hline 13 & 35 & 12 & $47 \%$ & 33 & 20 & 53 \\
\hline 14 & 39 & 37 & $75 \%$ & 14 & 10 & 24 \\
\hline & & & $48.3 \%$ & & & 51.7 \\
\hline
\end{tabular}

Table 8: Surmary or Espondent to Statement 12-14

Table 4.2: Shows that 100 respondents to the student 12.14 .

In all,48.3\% of respondent agreed with the research question while $51.7 \%$ of the respondent disagreed with the research questions. $22 \%$ and $47 \%$ of the respondent concord to research question 12 and 13 while $78 \%$ and $53 \%$ disagreed. This shows that teacher do make appropriate use of the internet technology $7 \%$ of the respondent agreed that Music assignment given to the student by the teacher can be easily gotten from the internet technology.

\subsection{Surmary of Respondent to 15-17}

\begin{tabular}{|c|c|c|c|c|c|c|}
\hline Statement & $\begin{array}{c}\text { Strongly } \\
\text { agreed }\end{array}$ & Agreed & $\mathbf{\%}$ & $\begin{array}{c}\text { Strongly } \\
\text { disagreed }\end{array}$ & Disagreed & \% \\
\hline 15 & 13 & 10 & 23 & 37 & 40 & 77 \\
\hline 16 & 23 & 22 & 45 & 35 & 20 & 55 \\
\hline 17 & 20 & 19 & 39 & 31 & 30 & 61 \\
\hline & & $35.7 \%$ & & & $64.36 \%$ \\
\hline
\end{tabular}

Shows that 100 respondents respond to the statement $15-17$ therefore,23\%, 40\% and 30\% of the respondent disagreed with statement 15-17.In all 35.7\% of the respondent agreed with the research question while $64.3 \%$ of the respondent with research questions. The table shows that 23\%, 5\% and 39\% of the respondent agreed to questions 15 $17 \%$ why77\%, 55\% and 61\% disagreed. This implies that teacher do not make use of internet technology in teaching Music, the internet in not enough and also the teacher are not good in the use of internet. 


\subsection{Statement of the Respondent to Statement 18.20}

\begin{tabular}{|c|c|c|c|c|c|c|}
\hline Statement & $\begin{array}{c}\text { Strongly } \\
\text { Agreed }\end{array}$ & Agreed & \% & $\begin{array}{c}\text { Strongly } \\
\text { Disagreed }\end{array}$ & Disagreed & \% \\
\hline 18 & 20 & 15 & 35 & 35 & 30 & 65 \\
\hline 19 & 23 & 18 & 41 & 39 & 20 & 59 \\
\hline 20 & 10 & 25 & 35 & 35 & 30 & 65 \\
\hline
\end{tabular}

Table 10

Shows that 1005 respondent to the statement 18-20 therefore, 36\%, 41\%, and 35\% of the respondent agreed to the statement $18-20$ while $65 \%, 59 \%$ and $65 \%$ of the respondent disagreed with the statement $18-20$.in all, 375 of the respondent agreed with the research questions.

The table shows that, 35\%,41\% and 35\% of the respondent agreed that with questions while $65 \%, 59$ and $65 \%$ disagreed to the questions. This shows that internet facilities does not work at all time "also power is not stable to power the internet.

\section{Discussion of Findings, Conclusion and Recommendation}

The finding of the study was discussed in reaction to the objective of the reaction to the objective of the study. Appropriately conclusion was drawn and recommendation made.

\subsection{Discussion Findings}

The study finds out that internet technology is very important catalyst in teaching and learning in music education and it is newly introduced in Nigerian education system. Unlike before its introduction which is not making learning to go at the student place, critically shows the important of internet technology of integrated in the learning of music education and finding also give a critical analysis and the finding also give critical analysis to the benefit and the possible problem which may be faced if use in the teaching and learning of music education through the questionnaire administrated with various response from respondents.

The research finding also reveal that the internet technology fertilities teaching and learning also if internet technology provide efficienciesin learning of music education if implement in school.

\subsection{Conclusion}

From the finding of this study, it can be concluded that internet technology had played a pivotal and indispensable roles in the effectiveness of teaching and learning in our schools due to some below highlighted reasons as aforementioned.

- Extend learning beyond what could be done.

- In the process of the interconnections of various subjects, it plays a central role.

- It help learners to learn on their pace.

- $\quad$ providing indebt knowledge of the content of the study. Etc.

With the very important role play by the internet technology in the teaching and learning process, some factors still serve as cankerworm in the use of internet technology for learning Music education our schools. These are:

- Inadequate electric supply.

- Instability of government policies.

- High cost of internet equipment.

- $\quad$ poor finance disbursement.

In view of this banner, in the use of internet technology, internet technology has really performed well in effective impacting Music education to learners.

\subsection{Recommendations}

Base on the research finding, the following recommendation were made to make internet technology effectively perform it role in the teaching of Music education.

The following are the recommendation:

- Government should provide effective information technology due to the fact that it will help in making teaching of Music easy in our schools.

- The cost of inquiring internet technology should be reduced from easy acquisition for internet technology.

- There should be stability in government policies. It should not be subject to frequent change or dynamic

- Qualified teachers should be recruited in schools.

\section{References}

i. Anderson R.E \& Becker H.J (2001) Teaching and computing 1999 national survey university of Minnesota.

ii. Bell L. (E.d) (2001) preparing teaching to use technology: perspective of the leader of twelve national education association. 
iii. Berson M.J (1999) effectiveness of computer technology in political science; are view of the literature journal of research on computing on education 28 (4),486-499.

iv. Bull G. Garofalo, J \&Harns (2000) grand challenge preparing for the technology hipping point learning and leading with technology, 29(8), 6-12.

v. Bodmer W.F. (2001) the public understanding of science London: the royal society.

vi. Casteem M. (199) Rise of the network society. Vol 1 Cambridge M.E black publishers.

vii. Cogan J.J Grossmmar D \&leim (2000) citizenship; the democratic imagination in a global context. Political education, 64(1)48-52.

viii. Cuban, l. (2001) over sold and under used: computer in the classroom Cambridge, M.A: Harrad University press.

ix. $\quad$ Durant J.r. Evans G.A (1999). The public understanding of science nature, 340, pp/11-14.

X. Ehman L.H \&Glem A.D (1999). Interactive technology in political science in J.P shaver (Ed); hand book of research on political science teaching and learning (pp.513-522)

xi. $\quad$ Fensham, P.J (2004) science from all journal of curriculum studies, 17pp.415-435

xii. Glenn A.d (2002) democracy and technology. The political science 81(59,215-17)

xiii. Gaskell J.P (2000) science technology and society: issues for science education 9pp .33-36.

xiv. Hodson D. (2003) teaching and learning science toward a personalized approach Buckingham open university press.

xv. Hadson D. (2003) time for action: science education for an alternative future international journal of science education, 25(6), pp.645-670.

xvi. Johnson C \& Rector J. (1999) the internet ten: using the internet to meet the music education curriculum standards science education, 61(3)167-169.

xvii. Media Awareness network (2000) web awareness: knowing issues retrieved march 6, 2000. 